\title{
Development of productive and reproductive potential of pregnant Red Chittagong cows through improved feeding in small scale dairy farm
}

\author{
Asaduzzaman M $^{1}$, MR Amin ${ }^{2 *}$, NR Sarkar ${ }^{1}$ and KS Huque ${ }^{1}$ \\ ${ }^{1}$ Bangladesh Livestock Research Institute, Savar, Dhaka, Bangladesh; ${ }^{2}$ Department of Animal Science, \\ Bangladesh Agricultural University, Mymensingh-2202, Bangladesh
}

\begin{abstract}
The aim of the experiment was to investigate the productive and reproductive potential of pregnant Red Chittagong (RC) cows through improved feeding. A total of 30 pregnant RC cows from each of 30 farmers having six months pregnancy and between 2 and 3 parities old were used in the trial. The cows were randomly allocated to three dietary treatment groups, i.e., $T_{0}, T_{1}$ and $T_{2}$. The cows of $T_{0}$ group received farmers' diet (63\% of dry matter intake of cows according to ARC, 1995) without the supplementation and served as control. The cows of $\mathrm{T}_{1}$ group received farmer's diet (63\%) plus $25 \%$ supplementation of formulated concentrate diet for deficit of requirement of cows $\{(63+9.25)=72.25 \%$ dry matter intake of cows according to ARC, 1995) $\}$ and $T_{2}$ group received farmers diet (63\%) plus formulated concentrate diet to meet $100 \%$ requirements of cows according to ARC $(1995)\{(63 \%+37 \%)=100 \%\}$. The total live weight gain before calving of RC cows were observed significantly $(P<0.05)$ higher in $\mathrm{T}_{2}$ and $\mathrm{T}_{1}$ groups than $T_{0}$ group. The calves birth weight was found significantly $(P<0.05)$ higher in $\mathrm{T}_{2}$ group than $\mathrm{T}_{1}$ and $\mathrm{T}_{0}$ groups. The gestation length was increased approximately 3 and 2 days for $T_{2}$ and $T_{1}$ groups, respectively, compared to $T_{0}$ group. Therefore, the farmer's diet plus supplementation of formulated concentrate diet to meet $100 \%$ requirement of cows according to ARC $(1995)\{(63 \%+37 \%)=100 \%\}$ was a better improved feeding system of pregnant Red Chittagong cows.
\end{abstract}

Key words: pregnant Red Chittagong cows, farmers' diet, improved feeding, live weight gain

\section{Introduction}

The agro-ecological zone determined the types and availability of feed resources as well as quality feed. The management and feeding practices of livestock are influenced by the local environment. In Bangladesh, feed resources of livestock are derived from crop residues and cereal by-product as well as grasses, tree leaves and aquatic plants, which are highly deficient in available nutrients to support the productive performances. Moreover, there is no recognized feeding system in Bangladesh. The farmers neither have scientific knowledge nor following any feeding system to satisfy the nutrient requirements of the cows. They offered feed based on their assumption and that is more or less requirement of the cows. However, the nutrient requirement of cattle is mainly depended on live weight, growth rate, stage of pregnancy and stage of lactation. Nutrient requirements for pregnant cows are most critical during the last trimester of the gestation period, when the developing fetus grows most (Ken Ziegler, 2009).

The problems associated with fertility failure in cows have been recognized today as a burning issue in cattle breeding program of Bangladesh (Alam, 1983). Failure of cows to become pregnant and the need for repeated insemination are the usual cause of economic loss to the dairy farmers (Quddus and Rahman, 1998), which might largely be due to inadequate nutrition. The prolonged interval of post-partum heat to the initiation of ovarian activity and low conception rate appeared to be the major constraints limiting dairy development in Bangladesh (Shamsuddin et al., 2001).

Chittagong is the largest division of Bangladesh and second in its importance to the capital Dhaka. The climate of Chittagong district is tropical in nature as it is situated in the tropical zone. The area features high, low and very low land with forest, variable soil type and diverse vegetation. The soil of Chttagong is bordered with a long costal belt and offshore islands on its western side. The entire landscape presents scenic blending of hills, valleys and coastal plain. The area consists of gently sloping loamy alluvial soil adjoining the eastern hills and extensive level of clay plain of three rivers. The district is remarkable for its uniform temperature, high humidity and heavy rainfall. The Red Chittagong cattle is found in Chittagong district of Bangladesh and easily distinguishable from others phenotypically by red coat color. Among the indigenous cattle of Bangladesh, Red Chittagong cattle is considered as an important variety of cattle for its genetic merit, unique characteristics, 
milk yield and meat production under local management practice (Akhter et al., 2002).

The feeding system of Red Chittagong cattle is traditional feeding and the diet consists of rice straw, naturally grown grasses and rice bran. Green fodder cultivation is very limited in Red Chittagong cattle raising areas and farmers usually allowed their animals to graze in fallow land and roadsides. Farmers also provide naturally grown grasses as well as agricultural weeds to Red Chittagong cattle by cut and carry system. The capable farmers supply little amount of concentrate feed but in general, quantity and quality of available feed resources are inadequate to meet the animals requirements. However, the productive and reproductive performances of pregnant Red Chittagong cows have not been studied so far in this country through improved feeding. Hence, the present study was undertaken with improved feeding under small- scale dairy farm in selected upazila of Chittagong district of Bangladesh.

\section{Materials and Methods}

Preparation of supplemented diet for pregnant Red Chittagong cows

The supplemented diet was prepared by mixing wheat bran, mustard oil cake, rice polish, rice bran, common salt and dicalcium phosphate in the proportions of 15, 18, 34, 29, 2 and $2 \mathrm{~kg}$ per 100 $\mathrm{kg}$, respectively to maintain the required levels of ME and CP. The ingredients are selected depending on the availability in the local market. Ingredients composition of formulated concentrate diet with energy and protein values is presented in Table 1.

Table 1. Ingredients composition of formulated concentrate diet with energy and protein values

\begin{tabular}{lc}
\hline Ingredients & Quantity (kg/100kg) \\
\hline Wheat bran & 15 \\
Mustard oil cake & 18 \\
Rice polish & 34 \\
Rice bran & 29 \\
Common salt & 2 \\
Dicalcium phosphate & 2 \\
Total & 100 \\
\hline Nutrient composition per kg DM \\
\hline ME $(\mathrm{MJ})$ & 8.07 \\
CP $(\mathrm{g})$ & 226 \\
\hline
\end{tabular}

Chemical composition of roughage and concentrate diet

The chemical composition of feed ingredients used in formulated concentrate diet and roughage feeds is shown in Table 2. The analysis of chemical composition is done by following the procedure of AOAC (2003). Metabolizable energy (ME) was determined by using the in-vitro gas production techniques (Menke et al., 1979). All the samples were analyzed in duplicate and mean values were recorded.

Table 2. Chemical composition of feed ingredients used in formulated concentrate diet and roughage feeds

\begin{tabular}{|c|c|c|c|c|c|c|c|c|}
\hline \multirow{2}{*}{$\begin{array}{l}\text { Feeds } \\
\text { ingredients }\end{array}$} & \multirow{2}{*}{$\begin{array}{c}\text { DM } \\
\text { (g/100g } \\
\text { sample) }\end{array}$} & \multicolumn{6}{|c|}{ Chemical composition (g/100g DM) } & \multirow{2}{*}{$\begin{array}{c}\text { ME (MJ/kg } \\
\text { DM) }\end{array}$} \\
\hline & & OM & CP & CF & EE & Ash & NFE & \\
\hline Rice straw & 87.50 & 86.80 & 3.50 & 51.23 & 1.92 & 13.13 & 45.70 & 5.38 \\
\hline Natural grasses & 16.00 & 91.07 & 11.67 & 37.50 & 1.60 & 8.90 & 54.60 & 7.29 \\
\hline Wheat bran & 87.85 & 93.24 & 11.91 & 8.50 & 13.18 & 6.16 & 57.98 & 9.85 \\
\hline Mustard oil cake & 89.50 & 92.95 & 27.59 & 9.10 & 7.88 & 6.90 & 66.70 & 10.22 \\
\hline Rice polish & 88.71 & 90.75 & 8.99 & 10.50 & 15.60 & 9.50 & 63.15 & 7.13 \\
\hline Rice bran & 89.07 & 93.33 & 7.82 & 36.80 & 9.53 & 11.40 & 34.42 & 6.81 \\
\hline
\end{tabular}

$D M$, Dry matter; OM, Organic matter; $C P$, Crude protein; CF, Crude fiber; EE, Ether extract; A, Ash; NFE, Nitrogen free extract; ME, Metabolizable energy; MJ , Mega joule

\section{Place and duration of the experiment}

The experiment was conducted under on-farm conditions of Satkania Upazila of Chittagong district in Bangladesh. The duration of experiment was three months from January 2011 to March 2011.

\section{Selection of pregnant Red Chittagong cows}

Thirty (30) pregnant RC cows of six months of pregnancy and parities between 2 (second) and 3 (third) were selected from each of the thirty (30) farmers and used in this experiment.

\section{Experimental layout and treatments}

The design of the experimental layout and treatments are shown in Table 3. The cows were randomly allocated to three dietary treatment groups, i.e., $T_{0}, T_{1}$ and $T_{2}$. The cows of $T_{0}$ group received farmers diet ( $63 \%$ of dry matter intake of cows according to ARC, 1995) without the supplementation of formulated concentrate diet (FCD), served as control. The cows of $\mathrm{T}_{1}$ group 
received farmer's diet (63\%) plus $25 \%$ supplementation of formulated concentrate diet (FCD) for deficit of requirement of cows $\{(63+$ $9.25)=72.25 \%$ dry matter intake of cows according to ARC 1995)\} and $T_{2}$ group received farmers diet $(63 \%)$ plus formulated concentrate diet (FCD) to meet $100 \%$ requirements of cows according to ARC $(1995)\{(63 \%+37 \%)=100 \%\}$.

Table 3. Lay-out of the experiment

\begin{tabular}{|c|c|c|c|c|}
\hline \multirow{2}{*}{ Parameters } & & \multicolumn{3}{|c|}{ Dietary treatments } \\
\hline & & $\mathbf{T}_{0}$ & $T_{1}$ & $T_{2}$ \\
\hline Number of pregnant RC cows & & 10 & 10 & 10 \\
\hline Duration of the trial (month) & & 3 & 3 & 3 \\
\hline Initial live weight (kg) & & $151.40 \pm 6.15$ & $151.30 \pm 8.19$ & $151.60 \pm 7.33$ \\
\hline $\begin{array}{l}\text { Formulated concentrate } \\
\text { supplementation }\end{array}$ & diet & $\begin{array}{l}\text { No } \\
\text { supplementation }\end{array}$ & $\begin{array}{l}1.12 \mathrm{~kg} / \text { day } \\
(25 \%)\end{array}$ & $\begin{array}{l}1.71 \\
(100 \%)\end{array}$ \\
\hline
\end{tabular}

\section{Housing and feeding practice of cows}

The experimental cows were kept in traditional housing. The supplement diet was carried out in order to correct the nutrient deficiency based on the comparison of control group that estimated following the ARC (1995). The roughages were given twice daily at between 06:00 to 07:30 hours in the morning and at between $15: 30$ to $16: 30$ hours in the afternoon. Rice straw was offered at the beginning followed by natural grasses. The total amount of formulated concentrate diet (FCD) was portioned into two and supplied in the morning at between 08:00 to 09:00 hours and afternoon at between $17: 00$ to $18: 30$ hours. The FCD was offered soon after feeding roughages. The total amount of FCD was adjusted based on the week of the experiment. The roughages and FCD were weighted and recorded before supplying. Fresh drinking water was accessed ad libitum to all the cows at all the times.

\section{Calculation of nutrient requirements}

The daily dry matter (DM), metabolizable energy (ME) and crude protein (CP) requirements of pregnant RC cows were calculated based on ARC (1995). The M/D values and CP values of feeds were also calculated based on ARC (1995).

\section{Estimation of feed and nutrient intake}

The feed was weighted daily before supplying. The leftover feeds were weighted and recorded on the following morning before offering morning feed. The daily feed intake was determined by subtracting the amount of leftover from the amount of feed given on the previous day. The metabolizable energy (ME) and crude protein (CP) was determined from the amount of dry matter (DM) fed in 24 hours. The ME and CP values were determined by multiplying respective $\mathrm{ME}$ and $\mathrm{CP}$ values of feeds.

Weight determination of pregnant Red Chittagong cows and birth weight of calves

The experimental cows were weighed individually at weekly interval and recorded regularly. The weight of RC cows was performed in the morning before feeding. The birth weight of calf was taken immediately after birth and recorded. The placenta was also weighed and recorded.

\section{Data collection and record keeping}

A formatted register was supplied to each of the thirty (30) farmers for recording of data on the experimental pregnant RC cows. The data on daily feed intake; weekly live weight, date of service, date of calving, calf birth weight and placenta weight were recorded regularly and collected for statistical analysis.

\section{Statistical analysis}

The collected data were analyzed statistically by using Compare Means (CM); Means procedure of One-Way Analysis of variance (ANOVA): Post Hoc Multiple Comparisons, Equal Variances Assumed by Duncan of SPSS 11.5 for Windows (SPSS Inc. 2004) statistical package.

\section{Results and Discussion}

\section{Improved feeding system}

The farmers feeding system was improved based on the deficit nutrient balance of pregnant cows by supplementing formulated concentrate diet (FCD) to make it improved feeding system. The Red Chittagong cattle is reported to be famous for its well adaptability, genetic merit, delicious meat and superior skin quality. Lower birth weight of RC calves could be improved by increasing live weight of cows. It is now well documented that supplementation with high protein and energy concentrate diet could improve the birth weight of calves and live weight gain of cows. Thus increase overall reproductive potential. The supply of nutrients required by animals in appropriate proportions is vital to optimize the productivity. This, in turn, requires knowledge of art and science of nutrition and diet formulation to meet physiological needs of animals. Animals are most productive when fed a diet balanced according to their nutrient need. The needed nutrients should also be supplied at lowest possible cost. This can 
be done if producers use locally available feed ingredients and use purchased feeds only to fill the deficit in nutrient supply.

\section{Nutrient intake, ARC (1995) requirement and nutritional status}

The nutrient intake, ARC (1995) requirement and nutritional status of pregnant experimental RC cows of three dietary treatment groups are shown in Table 4. In the present experiment, the dry matter, metabolizabl energy and crude protein intake of cows were deficit by $1.43 \mathrm{~kg}, 11.50 \mathrm{MJ}$ and $179 \mathrm{~g}$ and $0.39 \mathrm{~kg}, 3.10 \mathrm{MJ}$ and $55 \mathrm{~g}$, per day, respectively, for $T_{0}$ and $T_{1}$ groups (Table 4). On the other hand, the intake of DM, ME and CP of pregnant cows of $T_{2}$ group were fulfilled the requirement according to ARC (1995). The total DM $(\mathrm{kg} / \mathrm{d}), \operatorname{ME}(\mathrm{MJ} / \mathrm{d})$ and $\mathrm{CP}(\mathrm{g} / \mathrm{d})$ intake per $\mathrm{kg}$ metabolic $\left(\mathrm{W}^{0.75}\right)$ live weight were also deficit for $T_{0}$ and $T_{1}$ groups than the $T_{2}$ group.

\section{Feed and nutrient intake}

The feed and nutrient intake of pregnant experimental RC cows of three dietary treatment groups is shown in Table $\mathbf{5}$. The average live weight $(\mathrm{kg})$ and metabolic live weight $\left(\mathrm{kg} \mathrm{W}^{0.75}\right)$ of the experimental pregnant Red Chittagong cows were significantly $(P<0.05)$ higher in $T_{2}$ than $T_{1}$ and $T_{0}$ groups. It might be due to improve feeding supported the higher live weight gain.

\section{Dry matter intake}

In the present experiment, the dry matter intake of rice straw, natural grasses and rice bran were nonsignificant $(P>0.05)$ among the dietary treatment groups (Table 5). The total DM intake of improved feeding system and the farmers feeding system was varied significantly $(P<0.05)$. The variation might be due to supply of formulated concentrate diet $\left(T_{1}=1.12 \mathrm{~kg}\right.$ and $T_{2}=1.71 \mathrm{~kg}$ ). The percent of total DM intake was 63,87 and 100 , respectively, for $T_{0}, T_{1}$ and $T_{2}$. The findings of the present experiment supported by the findings of Ahmed (2006), who reported that the total DM intake of the pregnant cows of improved feeding group was significantly $(P<0.01)$ higher than that of the traditional feeding group. The total DM intake, $\mathrm{kg}$ per \% live weight was higher in $T_{2}$ than $T_{1}$ and $T_{0}$ groups and the total DM intake, g per $\mathrm{kg}$ metabolic live weight was also higher in $T_{2}$ than $T_{1}$ and $T_{0}$ groups.

Table 4. Nutrient intake, ARC (1995) requirement and nutritional status of pregnant cows

\begin{tabular}{|c|c|c|c|c|c|c|c|c|c|}
\hline \multirow{3}{*}{ Parameters } & \multicolumn{9}{|c|}{ Dietary treatment groups } \\
\hline & \multicolumn{3}{|c|}{$\mathbf{T}_{\mathbf{0}}$} & \multicolumn{3}{|c|}{$\mathbf{T}_{1}$} & \multicolumn{3}{|c|}{$\mathbf{T}_{\mathbf{2}}$} \\
\hline & $\begin{array}{c}\text { NI } \\
\pm \text { SED }\end{array}$ & $\begin{array}{c}\text { NR } \\
\pm \text { SED }\end{array}$ & NB & $\begin{array}{c}\text { NI } \\
\pm \text { SED }\end{array}$ & $\begin{array}{c}\text { NR } \\
\pm \text { SED }\end{array}$ & NB & $\begin{array}{c}\text { NI } \\
\pm \text { SED }\end{array}$ & $\begin{array}{c}\text { NR } \\
\pm \text { SED }\end{array}$ & NB \\
\hline ALW (kg) & \multicolumn{3}{|c|}{$158.30 \pm 1.32$} & \multicolumn{3}{|c|}{$164.68 \pm 2.22$} & \multicolumn{3}{|c|}{$171.72 \pm 3.41$} \\
\hline $\operatorname{AMLW}\left(\mathrm{kgW}^{0.75}\right)$ & \multicolumn{3}{|c|}{$44.63 \pm 1.04$} & \multicolumn{3}{|c|}{$45.96 \pm 0.46$} & \multicolumn{3}{|c|}{$47.41 \pm 0.72$} \\
\hline $\operatorname{TDM}(\mathrm{kg} / \mathrm{d})$ & $\begin{array}{l}2.97 \\
\pm 0.02\end{array}$ & $\begin{array}{l}4.40 \\
\pm 0.14\end{array}$ & -1.43 & $\begin{array}{c}4.09 \\
\pm 0.04\end{array}$ & $\begin{array}{l}4.48 \\
\pm 0.15\end{array}$ & -0.39 & $\begin{array}{c}4.68 \\
\pm 0.07\end{array}$ & $\begin{array}{c}4.68 \\
\pm 0.06\end{array}$ & 0 \\
\hline $\begin{array}{l}\text { TDM } \\
(\mathrm{kg} / 100 \mathrm{kgLW})\end{array}$ & $\begin{array}{c}1.87 \\
\pm 0.01\end{array}$ & $\begin{array}{c}2.78 \\
\pm 0.07\end{array}$ & -0.91 & $\begin{array}{c}2.48 \\
\pm 0.01\end{array}$ & $\begin{array}{c}2.72 \\
\pm 0.05\end{array}$ & -0.24 & $\begin{array}{c}2.72 \\
\pm 0.01\end{array}$ & $\begin{array}{c}2.72 \\
\pm 0.05\end{array}$ & 0 \\
\hline $\operatorname{TDM}\left(\mathrm{g} / \mathrm{kgW}^{0.75} / \mathrm{d}\right)$ & $\begin{array}{l}67 \\
\pm 0.39\end{array}$ & $\begin{aligned} & 98 \\
\pm & 2.58\end{aligned}$ & -31 & $\begin{array}{c}88 \\
\pm 0.28\end{array}$ & $\begin{aligned} & 97 \\
\pm & 2.35\end{aligned}$ & -9 & $\begin{array}{l}98.71 \\
\pm 0.17\end{array}$ & $\begin{array}{l}98.71 \\
\pm 2.07\end{array}$ & 0 \\
\hline $\operatorname{TME}(\mathrm{MJ} / \mathrm{d})$ & $\begin{array}{l}23.95 \\
\pm 0.23\end{array}$ & $\begin{array}{l}35.47 \\
\pm 1.15\end{array}$ & -11.52 & $\begin{array}{l}32.98 \\
\pm 0.35\end{array}$ & $\begin{array}{l}36.08 \\
\pm 1.24\end{array}$ & -3.10 & $\begin{array}{l}37.75 \\
\pm 0.56\end{array}$ & $\begin{array}{l}37.75 \\
\pm 1.35\end{array}$ & 0 \\
\hline $\operatorname{TME}\left(\mathrm{MJ} / \mathrm{kgW}^{0.75} / \mathrm{d}\right)$ & $\begin{array}{c}0.53 \\
\pm 0.03\end{array}$ & $\begin{array}{c}0.79 \\
\pm 0.02\end{array}$ & -0.26 & $\begin{array}{c}0.71 \\
\pm 0.01\end{array}$ & $\begin{array}{c}0.78 \\
\pm 0.02\end{array}$ & -0.07 & $\begin{array}{c}0.79 \\
\pm 0.01\end{array}$ & $\begin{array}{c}0.79 \\
\pm 0.01\end{array}$ & 0 \\
\hline $\mathrm{TCP}(\mathrm{g} / \mathrm{d})$ & $\begin{array}{c}235 \\
\pm 2.20\end{array}$ & $\begin{array}{c}414 \\
\pm 5.95\end{array}$ & -179 & $\begin{array}{l}376 \\
\pm 4.01\end{array}$ & $\begin{array}{c}431 \\
\pm 6.87\end{array}$ & -55 & $\begin{array}{c}450 \\
\pm 7.34\end{array}$ & $\begin{array}{c}450 \\
\pm 8.21\end{array}$ & 0 \\
\hline $\begin{array}{l}\text { TCP } \\
\left(\mathrm{g} / \mathrm{kgW}^{0.75} / \mathrm{d}\right)\end{array}$ & $\begin{array}{l}5.27 \\
\pm 0.04\end{array}$ & $\begin{array}{c}9.28 \\
\pm 0.29\end{array}$ & -4.01 & $\begin{array}{l}7.50 \\
\pm 0.01\end{array}$ & $\begin{array}{c}9.59 \\
\pm 0.27\end{array}$ & -2.09 & $\begin{array}{c}9.49 \\
\pm 0.02\end{array}$ & $\begin{array}{c}9.49 \\
\pm 0.25\end{array}$ & 0 \\
\hline $\mathrm{M} / \mathrm{D}(\mathrm{MJ} / \mathrm{DM})$ & $\begin{array}{l}8.06 \\
\pm 0.03\end{array}$ & $\begin{array}{l}11.94 \\
\pm 0.05\end{array}$ & -3.88 & $\begin{array}{l}8.06 \\
\pm 0.03\end{array}$ & $\begin{array}{l}9.45 \\
\pm 0.01\end{array}$ & -1.39 & $\begin{array}{c}8.06 \\
\pm 0.02\end{array}$ & $\begin{array}{l}8.06 \\
\pm 0.09\end{array}$ & 0 \\
\hline $\mathrm{CP}(\mathrm{g} / \mathrm{kg} \mathrm{DM})$ & $\begin{array}{l}79 \\
\pm 0.45\end{array}$ & $\begin{array}{c}139 \\
\pm 0.54\end{array}$ & -60 & $\begin{array}{c}92 \\
\pm 0.38\end{array}$ & $\begin{array}{c}115 \\
\pm 0.38\end{array}$ & -23 & $\begin{array}{c}96 \\
\pm 0.12\end{array}$ & $\begin{array}{l}96 \\
\pm 0.73\end{array}$ & 0 \\
\hline
\end{tabular}

$\mathrm{T}_{0}$ (control), Farmers diet (52\% dry matter intake of cows according to ARC, 1995); $\mathrm{T}_{1}$, Farmer's diet $+25 \%$ supplementation of formulated concentrate diet (FCD) of requirement of cows (73\% dry matter intake of cows according to ARC, 1995); $T_{2}$, Farmers diet + FCD to meet $100 \%$ requirements of cows according to ARC (1995); NI, Nutrient intake; NR, Nutrient requirement; NB, Nutrient balance; SED, Standard error difference; ALW, Average live weight; AMLW, Average metabolic live weight; TDM, Total dry matter, TME, Total metabolizable energy; $\mathrm{TCP}$, Total crude protein; $\mathrm{M} / \mathrm{D}$, Energy concentration of $\mathrm{kg}$ diet dry matter; $\mathrm{CP}$, Crude protein values of $\mathrm{kg}$ diet dry matter 


\section{Metabolizable energy intake}

The total ME intake of pregnant Red Chittagong cows was varied significantly $(P<0.05)$ among the three dietary treatment groups (Table 5). The ME intake of $\mathrm{T}_{2}$ group was significantly $(P<0.05)$ higher than that of $T_{1}$ and $T_{0}$ groups. The findings of the present study are in good agreement with the findings of Ahmed (2006), who reported that the total ME intake of the pregnant cows of improved feeding group was significantly $(P<0.01)$ higher than that of the traditional feeding group. The total ME $(\mathrm{MJ})$ intake per $\mathrm{kg}$ metabolic $\left(\mathrm{W}^{0.75}\right)$ live weight of $\mathrm{T}_{2}$ group was also significantly $(P<$ 0.05 ) higher than that of $T_{1}$ and $T_{0}$ groups.

\section{Crude protein intake}

The total CP intake was significantly $(P<0.05)$ higher in $T_{2}$ group than $T_{1}$ and $T_{0}$ groups (Table 5). The results of the present study are in good agreement with the findings of Ahmed (2006). The total CP intake $(\mathrm{g})$ per $\mathrm{kg}$ metabolic $\left(\mathrm{W}^{0.75}\right)$ live weight was also significantly $(P<0.05)$ higher in $\mathrm{T}_{2}$ than $T_{1}$ and $T_{0}$ groups. The higher $C P$ intake of $T_{2}$ group might be due to supply of nutrients to meet 100 percent nutrient requirement of pregnant RC cows according to ARC (1995).

\section{M/D and CP values of intake diet}

The M/D and CP values of intake diet of pregnant experimental RC cows of three dietary treatment groups is shown in Table 5. The $M / D$ and $C P$ values were significantly $(P<0.05)$ different among the three dietary treatment groups. The $M / D$ values of intake diet was significantly $(P<0.05)$ higher in $T_{2}$ than $T_{1}$ and $T_{0}$ groups. The $C P$ values was also significantly $(P<0.05)$ higher in $T_{2}$ than $\mathrm{T}_{1}$ and $\mathrm{T}_{0}$ groups. The higher $M / D$ and $C P$ values might be due to supply of FCD according to ARC (1995).

Table 5. Feed and nutrient intake of pregnant Red Chittagong cows

\begin{tabular}{|c|c|c|c|c|c|}
\hline \multirow[t]{2}{*}{ Parameters } & \multicolumn{3}{|c|}{ Dietary treatment groups } & \multirow[t]{2}{*}{ SED } & \multirow{2}{*}{$\begin{array}{l}\text { Level } \\
\text { of sig. }\end{array}$} \\
\hline & $\mathbf{T}_{\mathbf{0}}$ & $\mathbf{T}_{1}$ & $\mathbf{T}_{2}$ & & \\
\hline Average live weight $(\mathrm{kg})$ & $158.30^{c}$ & $164.68^{b}$ & $171.72^{\mathrm{a}}$ & 2.56 & $*$ \\
\hline Average metabolic live weight $\left(\mathrm{kgW}^{0.75}\right)$ & $44.63^{c}$ & $45.96^{b}$ & $47.41^{\mathrm{a}}$ & 1.17 & $*$ \\
\hline DM intake of rice straw ( $\mathrm{kg} /$ day) & 0.74 & 0.78 & 0.77 & 0.01 & NS \\
\hline DM intake of natural grasses ( $\mathrm{kg} /$ day) & 1.15 & 1.14 & 1.13 & 0.01 & NS \\
\hline DM intake of rice bran ( $\mathrm{kg} /$ day) & 1.08 & 1.05 & 1.09 & 0.02 & NS \\
\hline DM intake of FCD ( $\mathrm{kg} /$ day $)$ & 00 & 1.12 & 1.71 & - & - \\
\hline Total DM intake ( $\mathrm{kg} /$ day) & $2.97^{c}$ & $4.09^{b}$ & $4.68^{\mathrm{a}}$ & 0.82 & $*$ \\
\hline Total DM intake (kg/\%Live wt.) & $1.87^{\mathrm{c}}$ & $2.48^{\mathrm{b}}$ & $2.72^{\mathrm{a}}$ & 0.65 & $*$ \\
\hline Total DM intake ( $\left.\mathrm{g} / \mathrm{kgW}^{0.75} / \mathrm{day}\right)$ & $67^{c}$ & $88^{\mathrm{b}}$ & $98.71^{\mathrm{a}}$ & 4.02 & $*$ \\
\hline Total ME intake (MJ/day) & $23.95^{c}$ & $32.98^{\mathrm{b}}$ & $37.75^{a}$ & 2.64 & $*$ \\
\hline Total ME intake (MJ/ kgW $0.75 /$ day) & $0.53^{c}$ & $0.71^{b}$ & $0.79^{a}$ & 0.36 & $*$ \\
\hline Total CP intake (g/day) & $235^{c}$ & $376^{\mathrm{b}}$ & $450^{\mathrm{a}}$ & 10.24 & $*$ \\
\hline Total CP intake $\left(\mathrm{g} / \mathrm{kgW}^{0.75} /\right.$ day $)$ & $5.27^{c}$ & $7.50^{\mathrm{b}}$ & $9.49^{a}$ & 1.43 & $*$ \\
\hline$M / D$ values of intake diet (MJ/kg DM) & 8.06 & 8.06 & 8.06 & - & - \\
\hline $\mathrm{CP}$ values of intake diet ( $\mathrm{g} / \mathrm{kg} \mathrm{DM})$ & $79^{c}$ & $92^{b}$ & $96^{a}$ & 0.94 & $*$ \\
\hline
\end{tabular}

$\mathrm{T}_{0}$ (control), Farmers diet ( $52 \%$ dry matter intake of cows according to ARC, 1995); $\mathrm{T}_{1}$, Farmer's diet $+25 \%$ supplementation of formulated concentrate diet (FCD) of requirement of cows (73\% dry matter intake of cows according to ARC, 1995); $T_{2}$, Farmers diet + FCD to meet 100\% requirements of cows according to ARC (1995); LW, Live weight; NS, Nonsignificant; $*$, Significant at $5 \%$ level; ${ }^{a, b, c}$, Mean values having different superscripts in a row differed significantly; SED, Standard error difference

Table 6. Productive and reproductive performances of pregnant RC cows

\begin{tabular}{|c|c|c|c|c|c|}
\hline \multirow{2}{*}{ Parameters } & \multicolumn{3}{|c|}{ Dietary treatment groups } & \multirow{2}{*}{ SED } & \multirow{2}{*}{$\begin{array}{l}\text { Level of } \\
\text { sig. }\end{array}$} \\
\hline & $\mathbf{T}_{\mathbf{0}}$ & $\mathbf{T}_{1}$ & $\mathbf{T}_{\mathbf{2}}$ & & \\
\hline Initial live weight $(\mathrm{kg})$ & 151.40 & 151.30 & 151.60 & 1.53 & NS \\
\hline Final live weight $(\mathrm{kg})$ & $166.30^{c}$ & $177.80^{\mathrm{b}}$ & $192.20^{a}$ & 2.45 & $*$ \\
\hline Total live weight gain $(\mathrm{kg})$ & $14.90^{c}$ & $26.50^{\mathrm{b}}$ & $40.60^{\mathrm{a}}$ & 1.96 & * \\
\hline Daily live weight gain (g/day) & $165^{\mathrm{c}}$ & $296^{\mathrm{b}}$ & $451^{a}$ & 21.80 & $*$ \\
\hline Birth weight $(\mathrm{kg})$ of calf & $10.50^{c}$ & $13.75^{\mathrm{b}}$ & $16.85^{\mathrm{a}}$ & 1.78 & * \\
\hline Placenta weight $(\mathrm{kg})$ & $2.70^{\mathrm{b}}$ & $2.85^{\mathrm{b}}$ & $3.15^{\mathrm{a}}$ & 0.47 & * \\
\hline Calf plus placenta weight $(\mathrm{kg})$ & $13.20^{c}$ & $16.60^{\mathrm{b}}$ & $20.0^{\mathrm{a}}$ & 1.84 & * \\
\hline Gestation length (days) & $282.57^{c}$ & $284.45^{b}$ & $285.51^{a}$ & 0.99 & * \\
\hline
\end{tabular}

$\mathrm{T}_{0}$ (control), Farmers diet (52\% dry matter intake of cows according to ARC, 1995); $\mathrm{T}_{1}$, Farmer's diet $+25 \%$ supplementation of formulated concentrate diet (FCD) of requirement of cows (73\% dry matter intake of cows according to ARC, 1995); $T_{2}$, Farmers diet + FCD to meet $100 \%$ requirements of cows according to ARC (1995); LW, Live weight; NS, Nonsignificant; *, Significant at $5 \%$ level; ${ }^{a, b, c}$, Mean values having different superscripts in a row differed significantly; SED, Standard error difference 
Productive and reproductive performances of pregnant Red Chittagong cows

The productive and reproductive performances of pregnant RC cows of three dietary treatment groups are presented in Table 6.

\section{Live weight gain}

The average weekly live weight gain of pregnant RC cows in the present experiment were significantly $(P<0.05)$ higher in $T_{2}$ than $T_{1}$ and $T_{0}$ groups. The higher live weight in $T_{2}$ group might be due to supplementation of FCD to meet 100 percent requirement of cows according to ARC (1995). The live weight gain was 2.72 times higher in $\mathrm{T}_{2}$ group. The correlation between total live weight changes and intake of FCD was 93 percent, which indicated the strong relationship between live weight gain and intake of FCD. In the present study, it was found that the live weight increased by $0.24 \mathrm{~kg}$ with the increases of per percent of FCD.

\section{Birth and Placenta weight}

The average birth weight of calves were varied significantly $(P<0.05)$ among the three dietary treatment groups (Table 6). The higher birth weight of calf was recorded in $T_{2}$ group followed by the $T_{1}$ and $T_{0}$ groups. The higher birth weight of calf in $T_{2}$ might be due to better health of cows and subsequent foetal growth. Whereas, the lower calf birth weight in $T_{0}$ group may be due to poor heath as well as nutritional status and subsequent poor foetal growth during the pregnancy period. The calf birth weight was 60.47 percent higher in $\mathrm{T}_{2}$ group. The results of the present experiment were supported by Robinson (1990) who reported that the higher nutritional status of pregnant cows resulted in higher foetal growth during pregnancy. The placenta and calves plus placenta weight were significantly $(P<0.01)$ different among the three dietary treatment groups. The placenta and calves plus placenta weight were found higher in $\mathrm{T}_{2}$ group followed by $T_{1}$ and $T_{0}$ groups. Therefore, the increased live weight and live weight gain of cows and birth weight of calf in $T_{1}$ and $T_{2}$ groups are due to the improved feeding of FCD.

\section{Reproductive performances of pregnant Rd Chittagong cows}

In the present experiment, the factors affected on the reproductive performances of RC cows were constant to all treatment groups. The reproductive performances of cows are affected by the supplementation of FCD. O' Callaghan and Boland (1999) reported that the gestation length and calf birth weight are influenced by nutrition of cows. The results of the present study were also revealed that the gestation length and calf birth weight was influenced by nutritional status of cows. The gestation length was found significantly $(P<0.05)$ higher in $T_{2}$ than $T_{1}$ and $T_{0}$ groups. The gestation length was increased approximately 3 and 2 days for $T_{2}$ and $T_{1}$ groups, respectively, compared to $T_{0}$ group (Table 6 ). It might be due to better nutritional status of cows.

\section{Conclusion}

The results of the present experiment indicated that the farmers diet $(63 \%)$ plus $(+)$ formulated concentrate diet to meet $100 \%$ requirements of pregnant RC cows significantly increased the live weight gain of pregnant cows and birth weight of calves. Therefore, it is concluded that the farmer's diet with supplementation of formulated concentrate diet to meet 100 percent requirements of pregnant $R C$ cows is a better improved feeding system of pregnant RC cows and it may be recommended to use for the small-scale dairy farming system.

\section{References}

Ahmed TU (2006) Studies on nutritional status of dairy cows of Bangladesh and improvement of their productive and reproductive performance in Baghabarighat area through nutritional manipulation, PhD Thesis, Bangladesh Agricultural University, Mymensingh.

Akhter S, Huque KS, Jalil MA and Miah G (2002) Productive and reproductive performance of Red Chittagong, local cattle and their crossbred in different regions.In: Bangladesh Livestock Research Institute, Savar, Dhaka..

Alam MGS (1983) Research on animal reproduction. Bangladesh Agricultural University, Mymensingh. Livestock Advisor 8: 15 - 18.

AOAC (2003) Association of Official Agricultural Chemists. Official Methods of Analysis. $17^{\text {th }}$ edition. AOAC, Washington DC.

ARC (1995) Agricultural Research Council. the Nutrient Requirements of Ruminant Livestock. $C A B$ International, Wallingford, United Kingdom. 1995. P. $73-310$.

Ken Ziegler (2009) Management in the last trimester of pregnancy. Ag - Info Centre, toll-free in Alberta at 310 - FARM (3276), for agricultural information, (c) 2001 - 2010 Government of Alberta Copyright and Disclaimer.

Menke KHL, Raab L, Salewaskki A, Steingass H, Fritz $D$ and Schnerider W (1979) The estimation of digestibility and metabolizable energy content of ruminant feedstuffs from the gas production when they are incubated with rumen liquor in vitro. Journal of Agricultural Science 93: 217 222.

O'Callaghan D and Boland MP (1999) Nutritional effects on ovulation, embryo development and the establishment of pregnancy in ruminants. Journal of Animal Science 68: 299 - 314.

Quddus MA and Rahman MM (1998) Attitude by the rural farmer's towards artificial insemination service in Bangladesh. Bangladesh Journal of Animal Science 27: 83 - 92.

Robinson JJ (1990) Nutrition in the reproduction of farm animals. Nutrition Research Review 3253 276.

Shamsuddin M, Bhuiyan MMU, Sikder TK, Sugulle AH, Chanda PK, Galloway D and Alam MGS (2001) Constraints limiting the efficiency of artificial insemination of cattle in Bangladesh. IAEA, TECHDOC 1220: 9 - 27. 